\title{
Implementasi Model Guided Inquiry Berbantuan Media Pembelajaran SketchUp Pada Mata Kuliah Konstruksi Bangunan
}

\author{
Adrianus Zega ${ }^{* *}$, Maria Magdalena Zagoto ${ }^{2}$, Oskah Dakhi ${ }^{3}$
}

\author{
${ }^{1}$ IKIP Gunungsitoli, Sumatera Utara, Indonesia \\ ${ }^{2}$ Universitas Nias Raya, Sumatera Utara, Indonesia \\ ${ }^{3}$ Universitas Nias Raya, Sumatera Utara, Indonesia \\ * Corresponding-Author. Email: adri_zega80@yahoo.com
}

\begin{abstract}
Receive: $12 / 05 / 2021$
Accepted:04/08/2021

Published: 01/10/2021

Abstrak

Penelitian ini bertujuan untuk menjelaskan implementasi model Guided Inquiry berbantuan media pembelajaran SketchUp dalam pembelajaran Konstruksi Bangunan pada mahasiswa Program Studi Pendidikan Teknik Bangunan, IKIP Gunungsitoli. Penerapan model Guided Inquiry berbantuan media pembelajaran SketchUp berfokus pada skenario pembelajaran untuk memudahkan penyampaian materi dan melibatkan mahasiswa secara langsung dalam proses pembelajaran. Jenis penelitian ini adalah Penelitian Tindakan Kelas (PTK). Pelaksanaan penelitian ini pada semester genap TA. 2019/2020. Subyek penelitian ini adalah 25 mahasiswa Pendidikan Teknik Bangunan yang sedang mengikuti mata kuliah Konstruksi Bangunan. Teknik pengumpulan data yang digunakan adalah observasi, tes (terdiri dari post-test dan pre-test), dan wawancara untuk memperoleh data persepsi mahasiswa terhadap penerapan model pembelajaran dan aktivitas mahasiswa. Hasil penelitian menunjukkan bahwa hasil belajar mahasiswa pada aspek kognitif pada Siklus I sebesar 52\%, sedangkan Siklus II sebesar $80 \%$. Siklus pertama memiliki $60 \%$ dalam aspek psikomotor, sedangkan Siklus kedua adalah $76 \%$. Mengenai motivasi mahasiswa selama proses pembelajaran, Siklus I sebesar 49,92\%, sedangkan Siklus II sebesar 63,88\%. Berdasarkan temuan tersebut, implementasi model Guided Inquiry berbantuan media pembelajaran SketchUp dapat meningkatkan hasil belajar dan partisipasi mahasiswa dalam pembelajaran. Pelaksanaan proses pembelajaran mengalami peningkatan persentase sebesar $9 \%$. Penelitian ini menyimpulkan bahwa implementasi model Guided Inquiry berbantuan media pembelajaran SketchUp merupakan strategi atau alat pengajaran yang tepat dalam menyampaikan materi pada mata kuliah konstruksi bangunan dalam memotivasi mahasiswa dan melaksanakan pembelajaran serta meningkatkan hasil belajar mahasiswa.
\end{abstract}

Kata Kunci: model Inkuiri terbimbing, konstruksi bangunan, media pembelajaran SketchUp

\begin{abstract}
This study aims to explain the implementation of the Guided Inquiry model assisted by the SketchUp learning media in building construction learning for students of the Building Engineering Education Study Program, IKIP Gunungsitoli. Implementing the Guided Inquiry model assisted by the SketchUp learning media focuses on learning scenarios to facilitate the delivery of material and involve students directly in the learning process. The type of research is Classroom Action Research (CAR). The implementation of this research is in the even semester of TA. 2019/2020. The subjects of this study were 25 students of Building Engineering Education who were contracting building construction courses. Data collection techniques used were observation, tests (consisting of post-test and pre-test), and interviews to obtain data on student perceptions of the application of the learning model and student activities. The results showed that student learning outcomes in the cognitive aspect in Cycle I had 39\%, while Cycle II had 86\%. The first Cycle has 56\% in the psychomotor aspect, while the second Cycle is 67\%. Regarding student motivation during the learning process, Cycle I had 5.83\%, while Cycle II had 63.88\%. Based on these findings, implementing the Guided Inquiry model, assisted by the SketchUp learning media, can improve learning outcomes and student participation in learning. The execution of the learning process has increased by a percentage of 7\%. This research concludes that the SketchUp model with the Guided Inquiry model is an appropriate teaching strategy or tool in delivering material in building construction courses in motivating students and implementing learning and improving student learning outcomes.
\end{abstract}




\section{Pendahuluan}

Perubahan paradigma dari Teacher Centered Learning ke Student Centered Learning merupakan pembelajaran di mana mahasiswa sebagai subjek yang memiliki potensi untuk mengeksplorasi kemampuannya untuk belajar lebih aktif, mandiri dan kreatif sedangkan peran dosen hanya sebagai fasilitator/mitra belajar (Musfiqon \& Nurdyansyah, 2015, Rina, et al., 2020; Ferdiansyah, et al., 2020).

Pendekatan pembelajaran sebagai sudut pandang tehadap suatu proses yang sifatnya sangat umum kemudian strategi pembelajaran merupakan suatu kegiatan yang dilaksanakan oleh dosen agar tujuan pembelajaran tercapai (Telaumbanua, 2020). Metode merupakan cara untuk mengimplementasikan rencana yang sudah di susun dalam bentuk kegiatan nyata dan praktis untuk mencapai tujuan pembelajaran (Zagoto, et al., 2018).

Model pembelajaran merupakan satu rangkaian yang menjadi kesatuan yang utuh antara pendekatan, strategi, metode yang tergambar dari awal sampai akhir yang disajikan oleh dosen (Fajra, et al., 2020; Masril, et al., 2020; Timor, et al., 2020). Kegiatan pembelajaran yang diperlukan suatu evaluasi agar kriteria ketuntasan minimal mahasiswa dapat tercapai. Keaktifan mahasiswa dalam pembelajaran akan membentuk diri untuk lebih aktif dan kreatif dalam meningkatkan keaktifan belajar mahasiswa dalam pembelajaran (Anissa, et al., 2018; Mulhayatiah, 2014; Zagoto, et al., 2019).

Dengan kondisi yang terjadi sekarang ini, di semua penjuru dunia terjadi wabah virus covid 19 inilah saat yang tepat bagi Indonesia untuk menggunakan kemajuan IPTEK di segala bidang. Dikarenakan kondisi saat ini tidak memungkinkan untuk orang berpergian dan bergerombol (Dakhi, dkk., 2020). Dalam masalah ini, belajar mengajar yang semestinya bisa terlaksana dengan baik di kampus hanya bisa diaktualisasi melalui perantara media.
Dengan perantara media, dosen dapat menyampaikan materi dengan mudah.

Agar penyampaian materi dengan kodisi terbatas ini bisa di terima mahasiswa dengan maksimal. Dosen harus mempunyai kreatifitas dalam memaksimalkan penggunaan media pembelajaran yang ada (Zega, 2021). Begitu juga yang seharusnya terjadi pada mata kuliah Kontruksi Bangunan pada mahasiswa Prodi Pendidikan Teknik Bangunan, IKIP Gunungsitoli.

Menurut Arsyad (2011:5), media merupakan komponen sumber belajar atau wahana fisik yang mengandung materi instruksional di lingkungan mahasiswa yang dapat merangsang mahasiswa untuk belajar. Briggs (1970) menyatakan media adalah segala alat fisik yang dapat menyajikan peserta merangsang mahasiswa untuk belajar.

Masalah lain yang mengemukakan dalam penyampaian materi ini karena pemahaman dasar mahasiswa tentang mata pembelajaran yang kurang. Mahasiswa belum mampu mengimplementasikan materi yang di dapat dengan di lapangan. Selama proses pembelajaran online ini, mahasiswa banyak mendapatkan materi pembelajaran dari e-book maupun Power Point.

Menurut Harmanto

(2017:43) SketchUp adalah salah satu aplikasi untuk pemodelan 3 dimensi yang digunakan dan dirancang untuk para professional di bidang teknik sipil, arsitektur, pembuatan game, dan rancangan yang terkait didalamnya.

Oleh karena itu, penggunaan aplikasi SketchUp membantu memberikan pemahaman yang nantinya akan diberikan oleh dosen pada pembelajaran Konstruksi Bangunan.

Menurut Sudjana dan Rivai (2002:9) "Pengajaran akan lebih efektif apabila objek dan kejadian yang menjadi bahan pengajaran dapat divisualisasikan secara realistik atau menyerupai keadaaan yang sebenarnya, namun tdaklah berarti bahwa media harus selalu menyerupai keadaan yang sebenarnya". Sejalan dengan pedapat ahli di atas yang telah dijelaskan penggunaan media pembelajaran SketchUp pada mata pelajaran 
menggambar Konstruksi Bangunan diharapkan membantu membuat rangsangan dan ketertarikan terhadap mahasiswa dapat membantu untuk memahami secara utuh serta mampu membayangkan kondisi yang sebenarnya dari materi yang disampaikan oleh dosen, sehingga diharapkan nantinya ada peningkatan hasil belajar mahasiswa lebih baik dari pada sebelumnya.

Dari konteks uraian di atas, untuk mengetahui motivasi, hasil belajar, dan keterlaksanaan maka peneliti tertarik untuk meneliti mengenai implementasi model guided inquiry (inkuiri terbimbing) berbantuan media pembelajaran SketchUp untuk meningkatkan hasil belajar mahasiswa pada mata kuliah Kontruksi Bangunan.

\section{Metode}

Penelitian ini menggunakan desain penelitian deskriptif kualitatif. Subjek dalam penelitian ini adalah mahasiswa Prodi Pendidikan Teknik Bangunan yang mengontak mata kuliah Konstruksi Bangunan TA 2019/2020 sejumlah 25 orang. Metode pengumpulan data yang digunakan dalam penelitian ini adalah metode observasi, dokumentasi, dan angket. Dalam penelitian ini, peneliti menggunakan metode observasi non partisipatif (Salim, 2015). Peneliti memilih metode ini karena ingin melihat situasi belajar alami mahasiswa tanpa campur tangan peneliti. Dalam penelitian ini digunakan metode angket untuk memperoleh data pemahaman mahasiswa dengan menggunakan model pembelajaran berbasis proyek dan tugas mahasiswa sebagai tugas akhir. Setelah data terkumpul, dianalisis menggunakan analisis data deskriptif kualitatif.

\section{Hasil dan Pembahasan Hasil}

Hasil dan pembahasan akan menguraikan hasil penelitian yang telah dilaksanakan di Prodi Pendidikan Teknik Bangunan IKIP Gunungsitoli. Jumlah sampel pada penelitian ini sebanyak 25 mahasiswa pada semester genap tahun pelajaran 2019/2020.

\section{Siklus I}

\section{a. Tahap Perencanaan}

Pada sesi ini mengidentifikasi permasalahan serta pelaksanaan alternatif pemecahan permasalahan. Secara lebih khusus merupakan merancang proses pendidikan yang meliputi menentukan waktu proses belajar, menyusun perangkat pembelajaran semacam RPP, silabus, media pembelajaran, soal uji Siklus I. Dari perangkat pembelajaran tersebut akan di validasi oleh seorang validator yang berstatus sebagai dosen mata kuliah.

\section{b. Tahap Pelaksanaan}

Pelaksanaan penelitian dilakukan pada bulan Maret 2020. Dimana penelitian tersebut dilakukan sesuai rencana pembelajaran yang telah di buat dan dengan kondisi daring (zoom meeting).

\section{c. Tahap Pengamatan}

Tahap ini meliputi pengamatan proses belajar mengajar. Proses yang diamati meliputi proses pelaksanaan pembelajaran dan motivasi mahasiswa dalam pelaksanaan pembelajaran. Proses selanjutnya yaitu menganalisis kegiatan belajar mengajar untuk menentuk tahap selanjutnya.
1) Hasil Pengamatan Hasil Belajar Mahasiswa

Terdapat dua aspek pengamatan pada hasil belajar mahasiswa, yaitu aspek psikomotor dan aspek kognitif. Dalam pengamatan yang dilakukan pada siklus I mendapatkan hasil sebagai berikut:

\section{SIKLUS I ASPEK KOGNITIF}

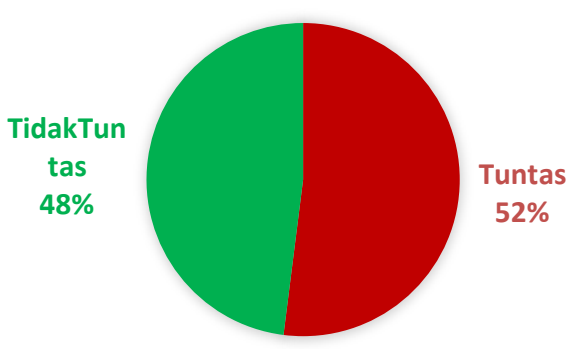




\section{Gambar 1. Grafik Hasil Belajar Aspek Kognitif Siklus 1}

Data hasil belajar ini diperoleh setelah pelaksanaan pokok bahasan tersampaikan. Pada kegiatan ini menjadi parameter peneliti untuk mentukan siklus selanjutnya. Dari grafik hasil uji di atas, persentase ketuntasan mahasiswa yang mendapat nilai $\geq 65$ hanya $52 \%$ atau sebanyak 13 orang.

\section{SIKLUS I ASPEK PSIKOMOTOR}

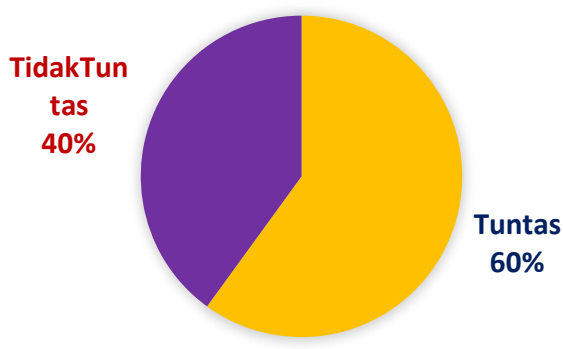

Gambar 2. Grafik Hasil Belajar Aspek

Psikomotor Siklus I

Data hasil tes Siklus I, didapatkan hasil sebesar $60 \%$ mahasiswa tuntas dalam tes psikomotor. Hasil ini dikategorikan "Cukup", dan pada siklus selanjutnya dapat di tingkatkan lagi.

\section{2) Hasil Pengamatan Motivasi Belajar Mahasiswa}

Tabel 1. Hasil Motivasi Belajar Mahasiswa

\begin{tabular}{|c|c|c|c|}
\hline \multirow{2}{*}{ No } & Pertemuan & \multicolumn{2}{|c|}{ Hasil Keterlaksanaan } \\
\cline { 3 - 4 } & Ke & Presentase & Kategori \\
\hline 1 & I & $46.84 \%$ & Cukup \\
\hline 2 & II & $53 \%$ & Cukup \\
\hline \multicolumn{2}{|c|}{ Rata-Rata } & $49,92 \%$ & Cukup \\
\hline
\end{tabular}

Dari hasil pengamatan, mendapatkan hasil bahwa motivasi mahasiswa dalam proses pembelajaran dapat dikategorikan "Cukup". Dimana motivasi mahasiswa dalam mengikuti pembelajaran dapat ditingkatkan kembali pada siklus berikutnya.

3) Hasil Pengamatan Keterlaksanaan Pembelajaran

Tabel 2. Rekapitulasi Hasil Keterlaksanann Pembelajaran

\begin{tabular}{|l|l|l|} 
No & Pertemuan & Hasil Keterlaksanaan
\end{tabular}

\begin{tabular}{|c|c|c|c|}
\hline & Ke & Presentase & Kategori \\
\hline 1 & I & $54 \%$ & Cukup \\
\hline 2 & II & $60 \%$ & Cukup \\
\hline \multicolumn{2}{|c|}{ Rata-Rata } & $57 \%$ & Cukup \\
\hline
\end{tabular}

Dari tabel di atas, hasil dari proses pembelajaran dengan implementasi model Guided Inquiry berbantuan media pembelajaran SketchUp terlaksana dengan "cukup". Artinya untuk pertemuan selanjutnya dosen dapat meningkatkan dengan baik.

\section{d. Refleksi}

Dalam proses penelitian Siklus I yang telah diamati, terdapat beberapa aspek yang harus diperbaiki. Beberapa aspek tersebut adalah:

1) Keterlaksanaan pada hasil motivasi belajar mahasiswa dikategorikan cukup. Pada siklus selanjutnya pembelajaran di buat semenarik mungkin dengan memperbaiki kembali media pembelajaran agar mahasiswa mudah dalam pemahamannya dan menarik motivasi belajar mahasiswa.

2) Hasil belajar mahasiswa ranah kognitif presentase ketuntasan adalah 52\%. Hal ini perlu adanya peningkatan karena kurang dari target yang di tentukan yaitu $\geq 75 \%$. Salah satu cara peningkatan tersebut dengan memperbaiki proses pembelajaran yang berlangsung dengan cara memancing mahasiswa dengan memberikan pertanyaan-pertanyaan yang mengarah pada pengeksplorasian pengetahuan mahasiswa nantinya.

\section{Siklus II}

\section{a. Tahap Perencanaan}

Tahap perencanaan ini menemukan masalah dan mencari solusi penyelesaian masalah pada Siklus I. Dengan langkah awal adalah merencanakan proses pembelajaran yang meliputi menentukan waktu pembelajaran, menyusun perangkat pembelajaran seperti RPP, silabus, media pembelajaran, soal tes Siklus II.

Dari perangkat pembelajaran tersebut akan di validasi oleh seorang validator yaitu dosen mata kuliah Konstruksi Bangunan. Pada tahap ini juga memperbaiki proses 
pembelajaran yang berlangsung agar kenaikan pada siklus tercapai.

Perbaikan pembelajaran seperti penyampaian materi yang lebih menarik perhatian mahasiswa, pembuatan media pembelajaran yang kreatif maka mahasiswa lebih aktif pada proses pembelajaran pada siklus II.

\section{b. Tahap Pelaksanaan}

Pelaksanaan penelitian dilakukan pada bulan Maret 2020. Dimana penelitian tersebut dilakukan sesuai rencana pembelajaran yang telah di buat dan dengan kondisi daring (zoom meeting).

\section{c. Tahap Pengamatan}

Tahap ini meliputi pengamatan proses belajar mengajar. Proses yang diamati meliputi proses pelaksanaan pembelajaran dan motivasi mahasiswa dalam pelaksanaan pembelajaran. Proses selanjutnya yaitu menganalisis kegiatan belajar mengajar untuk menentuk tahap selanjutnya.

1) Pengamatan Hasil Belajar

Terdapat dua aspek pengamatan pada hasil belajar mahasiswa, yaitu aspek psikomotor dan aspek kognitif. Dalam pengamatan yang dilakukan pada siklus II mendapatkan hasil sebagai berikut:

\section{SIKLUS II ASPEK KOGNITIF}

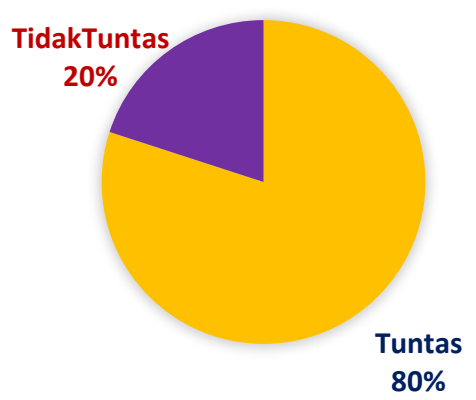

Gambar 3. Grafik Hasil Belajar Aspek Kognitif Siklus II

Grafik ketuntasan hasil belajar mahasiswa di atas menunjukkan bahwa $80 \%$ mahasiswa tuntas dalam hasil test pembelajaran pada siklus II. Itu menandakan kategori keberhasilan belajar mahasiswa di siklus ini sangat tinggi.

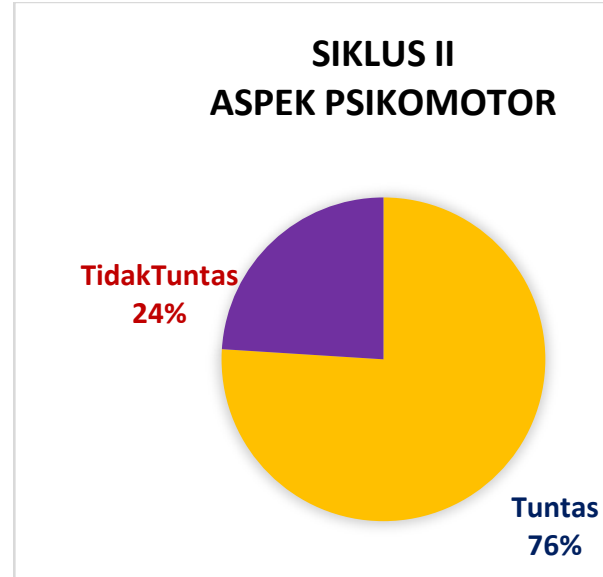

Gambar 4. Grafik Hasil Belajar Mahasiswa Psikomotor Siklus II

Dari grafik Siklus II ini, hasil tes psikomotor mahasiswa adalah $76 \%$. Ini dikategorikan dalam "Baik".

2) Hasil Pengamatan Motivasi Mahasiswa Tabel 3.Hasil Motivasi Belajar Mahasiswa

\begin{tabular}{|c|c|c|c|}
\hline \multirow{2}{*}{ No } & \multirow{2}{*}{$\begin{array}{c}\text { Pertemuan } \\
\mathrm{Ke}\end{array}$} & \multicolumn{2}{|c|}{ Hasil Keterlaksanaan } \\
\hline & & Presentase & Kategori \\
\hline 1 & I & $58,33 \%$ & Cukup \\
\hline 2 & II & $69,44 \%$ & Baik \\
\hline \multicolumn{2}{|c|}{ Rata-Rata } & $63,88 \%$ & Baik \\
\hline
\end{tabular}
pembelajar meningkat dengan prosentase menjadi $63.88 \%$ dengan kategori hasil pada siklus ini adalah "baik".

3) Hasil Pengamatan Keterlaksanaan Pembelajaran

Tabel 4. Rekapitulasi Hasil

Keterlaksanaan Pembelajaran

\begin{tabular}{|c|c|c|c|}
\hline \multirow{2}{*}{ No } & Pertemuan & \multicolumn{2}{|c|}{ Hasil Keterlaksanaan } \\
\cline { 3 - 4 } & I & Presentase & Kategori \\
\hline 1 & $66 \%$ & Baik \\
\hline 2 & II & $70 \%$ & Baik \\
\hline \multicolumn{2}{|c|}{ Rata-Rata } & $68 \%$ & Baik \\
\hline
\end{tabular}

Pada siklus ini, keterlaksanaan proses pembelajaran meningkat, artinya mahasiswa lebih mampu menangkap materi yang dijelaskan oleh dosen. Dan pada siklus ke dua ini, hasil dari keterlaksanaan proses pembelajaran di kategorikan "Baik".

\section{d. Refleksi}


Dalam tahap refleksi pada siklus II, terdapat hasil dari pelaksanaan yang dapat dicatat diantarannya:

1) Dari hasil belajar mahasiswa yang semakin meningkat, menunjukkan bahwa penguasan materi yang di terima mahasiswa semakin meningkat.

2) Pada siklus II, motivasi belajar dan rasa tanggung jawab mahasiswa dengan apa yang harus dikerjakan pada siklus ini sudah muncul.

3) Bertanggung jawab dengan apa yang harus di kerjakan.

4) Dari hasil pada penelitian motivasi dan hasil belajar mahasiswa mengalami peningkatan.

\section{Pembahasan}

1. Hasil Belajar Mahasiswa.

Setelah proses pelaksanaan pembelajaran, terdapat peningkatan hasil belajar mahasiswa yang ditunjukan melalui tes yang dilaksanakan setelah pembelajaran. Pada Siklus I dan II aspek kognitif mendapatkan hasil $52 \%$ menjadi $80 \%$. Hasil pada Siklus II lebih dari $75 \%$ dari kategori yang di targetkan.

2. Motivasi Belajar Mahasiswa.

Dalam proses belajar mengajar yang berlangsung motivasi mahasiswa dalam mengikuti proses pembelajaran mengalami peningkatan. Di mana pada Siklus I motivasi mahasiswa untuk mengikuti pembelajaran hanya sebesar 49,92\%. Dengan proses evaluasi dan perbaikan proses pembelajaran motivasi mahasiswa meningkat pada siklus selanjutnya menjadi $63.88 \%$.

3. Keterlaksanaan Pembelajaran.

Hasil pengamatan keterlaksanaan pembelajaran pada siklus I mendapatkan hasil seebesar 57\%, dan terjadi peningkatan hasil pada Siklus II sebesar $68 \%$. Dari hasil pengamatan, dapat disimpulkan bahwa pelaksanaan pembelajaran yang sudah direncanakan berlangsung secara baik.

\section{Simpulan}

Implementasi model Guided Inquiry berbantuan Media Pembelajaran SketcUp pada mata kuliah konstruksi bangunan berdampak positif pada hasil belajar. Baik hasil belajar aspek kognitf dan psikomotor, motivasi mahasiswa serta keterlaksanaan pembelajaran.

\section{Daftar Pustaka}

Anissa, R., Hsb, M. H. E., \& Damris, M. (2018). Peningkatan kemampuan berpikir kreatif siswa dengan menggunakan model project based learning berbasis STEAM (science, technology, engineering, arts dan mathematic) pada materi asam dan basa di SMAN 11 Kota Jambi. Journal of the Indonesia Society of Integrated Chemistry, 10 (2), 11-19.

Azhar, Arsyad. (2011). Media Pembelajaran. Jakarta: Rajawali Pers

Briggs, L., (1970). Principles of Instructional Design. New York: Holt, Rine hart and Winston.

Dakhi, O., Jama, J., Irfan, D., Ambiyar, Ishak. (2020). Blended Learning: A 21 st Century Learning Model At College. International Journal Of Multi Science, 1(8), 50-65.

Fajra, M., Ambiyar, A., Rizal, F., \& Dakhi, O. (2020). Pengembangan Model Evaluasi Kualitas Output Pembelajaran Teknik Komputer dan Jaringan di SMK Kota Padang. Cakrawala: Jurnal Pendidikan, 14(1), 1-9. https://doi.org/10.24905/cakrawala.v14 $\underline{\mathrm{i} 1.1480}$

Fajra, M., Jalinus, N., Jama, J., \& Dakhi, O. (2020). Model Pengembangan Kurikulum Sekolah Inklusi Berdasarkan Kebutuhan Perseorangan Anak Didik. Jurnal Pendidikan 21 (1), 51-63.

https://doi.org/10.33830/jp.v21i1.746.2 $\underline{020}$

Ferdiansyah, Ambiyar, Zagoto, M. M., Putra, I E D., (2020). Pemanfaatan Media Pembelajaran berbasis E Learning dalam Meningkatkan Hasil Belajar 
pada Matakuliah Media Pembelajaran Musik. Komposisi: Jurnal Pendidikan Bahasa, Sastra, dan Seni, 21(1), 062072.

DOI:

https://doi.org/10.24036/komposisi.v21 i1.108082

Harmanto. (2017). Media Animasi Pembelajaran Detail Konstruksi Bangunan Gedung 2 Lantai Menurut Standar Perencanaan Struktur Dengan 3D Google Sketchup. Jurnal Pend. Teknik Sipil dan Perencanaan FT UNY. Yogyakarta.

Masril, M., Dakhi, O., Nasution, T., Ambiyar. (2020). Analisis Gender Dan Intellectual Intelligence Terhadap Kreativitas. Edukasi: Jurnal Pendidikan, 18 (2), 182-191. https://doi.org/10.31571/edukasi.v18i2. $\underline{1847}$

Masril, M., Jalinus, N., Jama, J., \& Dakhi, O. (2020). Implementasi Pembelajaran Berbasis Masalah Pada Kurikulum 2013 Di SMK Negeri 2 Padang. Konstruktivisme: Jurnal Pendidikan Dan Pembelajaran , 12 (1), 12-25.

Musfiqon, \& Nurdyansyah. (2015). Pendekatan pembelajaran saintifik. Sidoarjo: Nizamia Learning Center.

Mulhayatiah, D. (2014). Penerapan Model Pembelajaran Berbasis proyek Unruk Meningkatkan Kemampuan Berfikir Kreatif Mahasiswa. Edusains. 6(1), 1822.

Rina Novalinda, Oskah Dakhi, Melda Fajra, Azmil Azman, Mardhiah Masril, Ambiyar,Unung Verawadina (2020). Learning Model Team Assisted Individualization Assisted Module to Improve Social Interaction and Student Learning Achievement. Universal Journal of Educational Research, 8(12A), 7974 7980.

DOI:

10.13189/ujer.2020.082585.

Salim, H. (2015). Penelitian Tindakan Kelas. Medan: Perdana Publishing.
Sudjana, Nana dan Ahmad Rivai. (2002). Media Pengajaran. Bandung: Sinar Baru Algesindo.

Telaumbanua, A. (2020). Kontribusi Persepsi Siswa Tentang Sekolah Menengah Kejuruan dan Cara Belajar Terhadap Hasil Belajar Siswa Sekolah Menengah Kejuruan (SMK) Negeri 1 Hiliserangkai. Jurnal Edukasi Sumba (JES), 4(1):1-9. http://jurnalstkipweetebula.ac.id/index.php/jes/article/vi $\underline{\mathrm{ew} / 80}$

Telaumbanua, A. (2020b). Upaya Pembentukan Kemandirian Mahasiswa Melalui Penerapan Model Pembelajaran Problem Based Instruction Pada Mata Kuliah Praktek Batu. Jurnal Review Pendidikan dan Pengajaran, 3(2), 436-444.

Timor, A. R., Ambiyar, A., Dakhi, O., Verawardina, U., \& Zagoto, M. M. (2020). Effectiveness of problem-based model learning on learning outcomes and student learning motivation in basic electronic subjects. International journal of multi science, 1(10), 1-8

Zagoto, Maria M., Yarni, Nevi; Dakhi, O. (2019). Perbedaan Individu dari Gaya Belajarnya Serta Implikasinya Dalam Pembelajaran. Jurnal Review Pendidikan dan Pengajaran, 2(2), 259265.

Zagoto, Maria M. \& Dakhi, O (2018). Pengembangan Perangkat Pembelajaran Matematika Peminatan Berbasis Pendekatan Saintifik Untuk Siswa Kelas XI Sekolah Menengah Atas. Jurnal Review Pendidikan dan Pengajaran, 1(1), 157-170.

Zega, A. (2021). Penerapan Model Project Based Learning (PjBL) dalam Mata Kuliah Konstruksi Bangunan Pada Mahasiswa Prodi Teknik Bangunan IKIP Gunungsitoli. Edumaspul: Jurnal Pendidikan, 5(1), 622-626. Retrieved from https://ummaspul.ejournal.id/maspuljr/article/view/1884 


\section{Profil Penulis 1}

Adrianus Zega, S.T., M.Psi. Lahir pada 14 Januari 1970. Penulis adalah dosen tetap di Prodi Pendidikan Teknik Bangunan, Fakultas Pendidikan Teknologi dan Kejuruan (FPTK), IKIP Gunungsitoli, Sumatera Utara. Penulis Lulus S1 pada tahun 1998 pada Program Studi Teknik Sipil, Universitas HKBP Nomensen. dan Lulus S2 pada tahun 2015 pada Program studi Psikologi, Universitas Medan Area.

\section{Profil Penulis 2}

Maria Magdalena Zagoto. Lahir pada 29 September 1991. Penulis adalah dosen tetap di Prodi Pendidikan Matematika, FKIP, Universitas Nias Raya, Sumatera Utara. Penulis adalah mahasiswa program Doctoral (S3) pada Fakultas Ilmu Pendidikan,
Universitas Negeri Padang, Sumatera Barat. Penulis Lulus S1 pada tahun 2013 pada Program Studi Pendidikan Matematika, STKIP Nias Selatan. dan Lulus S2 pada tahun 2016 pada Program Pendidikan Matematika, Universitas Negeri Padang.

\section{Profil Penulis 3}

Oskah Dakhi, Lahir pada 17 Pebruari 1989. Penulis adalah mahasiswa program Doctoral (S3) pada Fakultas Teknik Pendidikan Teknologi dan Kejuruan, Universitas Negeri Padang, Sumatera Barat. Penulis Lulus S1 pada tahun 2012 pada Program Studi Teknik Informatika, STMIK Budidarma Medan. dan Lulus S2 pada tahun 2014 pada Program studi Ilmu Komputer, Universitas Putra Indonesia, YPTK Padang. 